\title{
Evaluation Performance of Social Organization in Setu District - South Tangerang
}

\author{
Rahmi Andini Syamsuddin, Lisdawati, Agung Tri Putranto \\ Faculty of Economics, Universitas Pamulang, Tangerang Selatan \\ dosen02062@unpam.ac.id; dosen02115@unpam.ac.id; agung.tputranto@gmail.com
}

\begin{tabular}{|l}
\hline \\
\hline How to cite (in APA style): \\
Syamsuddin, Rahmi A., Lisdawati, \& Putranto, Agung Tri. (Years). Evaluation Performance of Social Organization in \\
Setu District - South Tangerang. Jurnal Ekonomi dan Bisnis Jagaditha, 7 (2), 123-127. doi: \\
https://doi.org/10.2225/jj.7.2.2483.51-55
\end{tabular}

\begin{abstract}
This study aims to measure the performance of Posyantek as a social organization in community empowerment in Setu District, South Tangerang. This study was designed in a qualitative descriptive type using data collection methods through interviews, observation, and documentation. Researchers will use indicators including productivity, service quality, responsiveness, responsibility, accountability in measuring the performance of Posyantek. The results obtained that there are still low-performance indicators, i.e. responsibility and accountability indicators. There is always a lack of communication between Posyantek and the surrounding community, which causes some Posyantek programs that are not running well. The insufficient number of Posyantek employees who are proficient in IT also causes the TTG program to be less than optimal. The absence of a standard organizational structure so that the flow of activities, especially TTG, is still not targeted.
\end{abstract}

Keywords: Social Organization, TTG, Performance

\section{INTRODUCTION}

Development helps to fulfill real facilities such as buildings, bridges, roads, or temporary assistance provided to the community. Development should also pay attention to the quality of its human resources by making human resources independent with their skills, this can indirectly help them escape poverty (Tewu, 2015). Therefore, the main factor of poverty lies in the quality of human resources from an area, which is the focus of this study. A portion of the population who are not successful in entering into formal sector activities will try to enter informal sector activities because the informal sector is a sector where it is not difficult for anyone to enter without special skills (Syamsuddin, 2020). Increase community quality by empowering the community by providing knowledge and training to develop themselves. Factors such as the level of experience and education of skilled workers, and access to sources of finance, access to development institutions are internal factors that can improve performance (Sani, Wiliani, Budiyantara, \& Nawaningtyas, 2020).

One of the developments carried out in Setu District is to focus on increasing community empowerment. Empowerment is an effort made by facilitating the community in managing their resources. Also, an assignment is an effort to encourage people to be smarter in utilizing their environment to achieve longterm sustainability.

The type of empowerment per the Decree of the Minister of Home Affairs number 20 of 2010 is about community empowerment using appropriate technology (TTG). This technology encourages the movement of human life patterns towards a more modern and practical direction. The application that appears is the result of technology development, which is currently a tool used in almost all human activities globally, including Indonesia (Sani, Wiliani, \& T, 2019). For the use of TTG to be efficient, effective, and synergized between the central government, local government, and the community, 
especially at the sub-district level, an Appropriate Technology Service Post (Posyantek) was formed which was responsible for providing technical services, information, promotion, and orientation of TTG to the community (Permendagri, 2010).

Posyantek is a social institution that can help solve problems in the social and economic environment (Hishiyama, 2013). Tidak hanya itu, rendahnya visi bisnis, pengetahuan dan keterampilan membuat tidak berkembangnya sektor bisnis yang berdampak pada aktivitas pemasaran, pengelolaan keuangan dan manajemen termasuk pengembangan produk yang lemah (Asraf \& Yuliza, 2018). To realize this program, Posyantek at the City and District level throughout Indonesia requires competent human resources in their respective fields. The plans that have been launched by the Ministry of Home Affairs can be realized and on target (Purnomo, Syamsuddin, Prabowo, Sularmi, \& Pratama, 2020).

Talented human resources can accelerate the nation's growth. To become a developed and productive resource, the population must have the adequate quality to become a sufficient development capital. The problem faced in Indonesia today is that there are still many Indonesian human resources which are still working that are not following their competencies and fields so that in carrying out their duties, they are still far from the standard of work so that the results of their products are not sufficient and efficient (Kementerian, 2019).

The optimal use of TTG by the community will realize community efforts that can streamline production costs, improve production quality processes, increase capacity, and add value to products. The community's welfare, improves people's lives, and can eradicate poverty (Husnul, 2016). Optimal use of this technology will have to pay attention to updating information with the factor of format, ease of use, and timeliness as well as interface design with a user-friendly appearance (Husain \& Budiyantara, 2018), this will be realized if there is technology transfer from the creator or owner of TTG to the user community.

The use of advances in technology and easy and inexpensive access by the public requires data and information processing, work processes, and an electronic management system (Dewi \& Rini, 2018). TTG transfer is carried out through the corrective efforts of TTG. Given certain factors, such as gaps in access to information, limited capital, and geographic constraints, in transferring technology, especially Appropriate Technology (TTG) to the community, government intervention is required for its acceleration.

The success of an organization in achieving its goals cannot be separated from the existence of human resources that the organization has to help manifest in the form of the organizational performance itself. Performance is the result of the work function of a person or group in an organization for a certain period that reflects how well a person or group meets the requirements of a job to achieve organizational goals (Bernardin \& Russel, 2003). Furthermore, the term performance comes from the word actual performance/job performance (work performance achieved by someone). This concept is a concrete work that can be observed and measured according to their responsibilities (Mangkunegara, 2017).

This research is intended to identify the level of performance and the factors that affect the performance of Posyantek (Appropriate Service Post) in community empowerment in Setu District, South Tangerang, in 2019. This research was conducted to achieve the goal of knowing how the level of performance, the factors, and knowing the steps taken to achieve the performance of Posyantek (Appropriate Service Post) in community empowerment in Setu District, South Tangerang in 2019.

\section{METHOD}

According to Sugiyono (2016), that descriptive qualitative research is a research method based on the philosophy of postpositivism which is usually used to research in natural objective conditions where the researcher acts as a key instrument. Meanwhile, (Nawawi \& Martini, 1994) define a descriptive method as a method that describes an objective state or individual event based on visible or appropriate facts, which are then accompanied by efforts to draw general conclusions these historical facts. 
Some of the data collection techniques used by researchers are as follows:

- Observation, namely data collection techniques, by making direct observations in everything being researched.

- Structured interviews, namely, data collection, using a questionnaire instrument.

- In-depth interviews, namely data collection, by conducting in-depth interviews with key informants.

\section{RESULTS AND DISCUSSION}

Performance of Posyantek (Appropriate Service Post) in community empowerment in Setu District, South Tangerang

From the results of this study, it can be seen that the performance of Posyantek (Appropriate Service Post) in community empowerment in Setu District, South Tangerang in 2019, has not been too good. This can be seen from several performance indicators or assessment criteria, namely:

\section{Productivity}

Productivity is an important indicator to measure the performance of an organization because productivity measures not only the level of efficiency but also its effectiveness. These can even understand the ratio between the input and output of an organization, where the input and output will provide a clear picture of the extent to which the organization has achieved its maximum productivity following the expected goals.

Based on the interviews with several informants, it can be seen that the productivity of Posyantek, Setu District, is currently not optimal. Concerning organizational inputs such as human resources and operational budgets, Posyantek, Setu District, is still inadequate. As for the output, such as achieving corporate targets, in this case, Posyantek in empowering the community. The target of Posyantek in Setu District is to provide technical services, information, promotion, and orientation on appropriate technology (TTG) to the community, especially in the District of Setu.

In general, the achievement of this target is quite good, and this can be seen from the Posyantek targets in Setu District that have been achieved. Implementing the development of Appropriate Technology Services (PTTG) is accepted and implemented by the community. The introduction of technology developed in society is the technology that has been developed traditionally, or what is known as "appropriate technology" or simple technology. Its opening is determined mainly by environmental conditions and the basic livelihoods of a particular community. Posyantek has carried out its duties by providing guidance. , training, mentoring, which in the end, the results are created to be effective and can compete in industry 4.0.

\section{Service Quality}

Service quality is a crucial indicator of how public organizations have provided service satisfaction to the public or service users. This makes researchers want to see the size to which Posyantek District Setum provides services in empowering the surrounding community. Starting from how Posyantek managers and operators must optimize the secretariat and existing information technology tools to optimize benefits to UKM-UKM spread across the districts. This aims to enable existing SMEs to use appropriate technology assisted by Posyantek as a center for technology dissemination, socialization, and diffusion.

\section{Responsiveness}

Responsiveness is the ability of an organization to recognize the needs of the community to formulate service agendas and priorities in developing public service programs according to community needs and aspirations. Responsiveness is needed in available services because it proves the organization's ability to identify community needs, establish service agendas and priorities, and develop public service programs according to community needs and aspirations.

Apart from the problem of IT proficiency from the operator, to support the optimization of Posyantek, its efforts should make from various parties that should be made. Starting from how Posyantek managers and operators must optimize the secretariat and existing information technology tools to optimize services to UKM-UKM spread across the 
districts. This aims to enable existing SMEs to use appropriate technology assisted by Posyantek as a center for technology dissemination, socialization, and diffusion. What kind of technology can help the SME community increase their productivity, such as user manuals, to crowd-sourced useful technology tools? Maybe one of the issues why Posyantek is an essential institutional aspect concerning SMEs and (appropriate) technology.

\section{Responsibility}

Responsibility describes whether implementing a public organization is carried out following correct administrative principles or by organizational policies, both explicit and implicit. In terms of implementing its activities, Posyantek will map the need for appropriate technology, which is the first step in implementing TTG activities. Requirements mapping is carried out to identify potentials and problems that exist in the area or village. Mapping of needs is done through collecting data and information on types of TTG, types of community businesses, socio-culture, and potential local resources. Mapping of needs is meant not only in manual/statistical data, but also a thematic map depicting an area or area complete with its potential resources and businesses. The results of the analysis of the iron table demand mapping conducted by Posyantek went well. Data collection was carried out in various regions by looking at multiple types of businesses and local resource potentials summarized in a document in the form of a table. Posyantek has carried out manual needs mapping where there is no map image showing potential areas in the community.

\section{Accountability}

Public accountability refers to how much the policies and activities of public organizations are subject to public officials elected by the people. In this context, the concept of public accountability can be used to see how much the policies and activities of public organizations are consistent with the will of the people. The performance of public organizations can not only be seen from the internal measures developed by public organizations or governments, such as the achievement of targets. Performance should be judged from an external effort, such as the values prevailing in society. An activity of a public organization has high accountability if the action is considered accurate and following the norm values that develop in society. In the Minister of Home Affairs Regulation No. 20/2010 concerning Community Empowerment through Appropriate Technology Management, the term Posyantekdes is changed to Posyantek (Appropriate Technology Service Post). In the framework of fostering and developing Posyantek, the Directorate General of Community and Village Empowerment, the Ministry of Home Affairs compiled General Guidelines for Posyantek Management.

\section{CONCLUSION}

In this study, we want to develop Appropriate Technology Services (PTTG) so that the community can accept the use of PTTG by providing guidance, training, mentoring, which ultimately results in being effective and can compete in industry 4.0. Therefore, the management of existing human resources for Posyantek employees requires increased competence so that the use of Appropriate Technology (TTG) can be appropriately understood, and knowledge of competition in Industry 4.0 can be answered effectively and efficiently.

To improve the community development business system to make it more productive and efficient does not appear technology is needed. The introduction of technology developed in society is the technology that has been developed traditionally, or what is known as "appropriate technology" or simple technology. Its opening is determined mainly by environmental conditions and the basic livelihoods of a particular community.

To achieve the goals of Posyantek in implementing appropriate technology. Effectively and efficiently in welcoming the industrial era 4.0, several suggestions need to be improved, namely: (1) Communication here is vital because success in communicating between Posyantek organizers and the community will facilitate the programs the Posyantek program can run well; (2) Human 
resources by increasing the number of staff implementing the TTG program so that they can reach the implementation of the TTG program to remote areas; and (3) an excellent organizational structure so that the flow of TTG activities can be right on target so that the Work Operational Standard can be used as a reference for work.

\section{REFERENCES}

Asraf, \& Yuliza, M. (2018). Meningkatkan Usaha Produksi Kacang Garing / Kacang Goreng Taulu Guna Peningkatan Perekonomian dan Kesejahteraan Pengrajin. Jurnal Vokasi, 2(1), 32-39.

Bernardin, H. J., \& Russel, J. E. (2003). Human resource management: An experimental approach (International ed.). Singapore: Mc.Graw-Hill Inc.

Dewi, N. W., \& Rini, I. G. (2018). Pengaruh Pengawasan keuangan, Sumber daya manusia, Teknologi Informasi, dan Pengendalian Intern Terhadap Nilai Informasi Pelaporan Keuangan Pemerintah Daerah Kabupaten Tabanan. KRISNA: Kumpulan Riset Akuntansi, 10(1), 63-69.

Hishiyama, R. (2013). Sustainable Empowerment Models for Rural Pastoral Communities in Kenya. Procedia - Social and Behavioral Sciences, 85, 432-442. Retrieved from https://doi.org/10.1016/j.sbspro.2013.08.372

Husain, T., \& Budiyantara, A. (2018). Analisis End-User Computing Satisfaction (EUCS) Dan WebQual 4.0 Terhadap Kepuasan Pengguna. Jatisi, 4(2), 164-176.

Husnul, F. (2016). Manajemen Pos Pelayanan Teknologi (Posyantek) Nagari Tuo Kecamatan Pariangan Kabupaten Tanah Datar dalam Pengelolaan Teknologi Tepat Guna. Padang: Universitas Andalas.

Kementerian, S. N. R. (2019). Pembangunan Sumber Daya Manusia (SDM) Menuju Indonesia Unggul.

Mangkunegara, A. A. (2017). Manajemen Sumber Daya Manusia. Bandung: Remaja Rosdakarya.

Nawawi, H., \& Martini, M. (1994). Penelitian Terapan. Yogyakarta: Gadjah Mada.

Permendagri. (2010). Peraturan Menteri Dalam Negeri tentang Pemberdayaan Masyarakat melalui Pengelolaan Teknologi Tepat Guna. Jakarta.

Purnomo, S., Syamsuddin, R. A., Prabowo, B., Sularmi, L., \& Pratama, A. (2020). Peningkatan Kualitas Pengurus Posyantek Menjadi SDM yang Unggul dalam
Menyongsong Era Industri 4.0. Abdi Laksana: Jurnal Pengabdian Kepada Masyrakat, 1(2), 263-270.

Sani, A., Wiliani, N., Budiyantara, A., \& Nawaningtyas, N. (2020). Pengembangan Model Adopsi Teknologi Informasi Terhadap Model Penerimaan Teknologi diantara UMKM. JITK (Jurnal Ilmu Pengetahuan Dan Teknologi Komputer), 5(2), 151-158.

Sani, A., Wiliani, N., \& T, H. (2019). Spreadsheet Usability Testing in Nielsen's Model among Users of ITSMEs to Improve Company Performance. European Journal of Scientific Exploration, 2(6), 1-9.

Sugiyono. (2016). Metode Penelitian Kombinasi (Mixed Methods). (M. Sutopo, Ed.). Bandung: CV. Alfabeta.

Syamsuddin, R. A. (2020). Kinerja Satuan Polisi Pamong Praja (Satpolpp) Kecamatan Serpong dalam Penertiban Pedagang Kaki Lima (PKL) di Pasar Serpong. Jurnal Semarak, 3(1), 1-19.

Tewu, M. E. (2015). Peranan Sumber Daya Manusia dalam Meningkatkan Aktivitas Kelompok Tani di Desa Tember. E-Journal “Acta Diurna, IV(3), 1-16. 